\title{
Reframing Corporate Social Responsibility and Sustainability in the Aftermath of United Nations 2030 Agenda: An Empirical Study into the Tanker and Dry Bulk Maritime Sector
}

\section{Ioannis Fasoulis}

Department of Naval Architecture Ocean and Marine Engineering, University of Strathclyde, Glasgow, UK ioannis.fasoulis@strath.ac.uk

\author{
Dr. Rafet Emek Kurt
}

Department of Naval Architecture Ocean and Marine Engineering, University of Strathclyde, Glasgow, UK rafet.kurt@strath.ac.uk

Publication Information:

Received 8 May 2019, Accepted 12 June 2019, Available online 15 June 2019

DOI: 10.21463/jmic.2019.08.1.06

\section{Abstract}

Corporate social responsibility (CSR) and sustainable development constitute an integral component of organization's strategy. Nowadays, growing environmental concerns have triggered a plethora of social initiatives and regulatory regimes. In view of United Nations 2030 Agenda, the International Maritime Organization (IMO) and the European Union (EU) have stressed the leading and efficient attributes of shipping transport and committed themselves to the achievement of global sustainability mandates. Similarly, CSR has been identified as a strategic approach to manage sustainability challenges. However, with the exception of few shipping segments, CSR refers to a, relatively, newly introduced notion to the shipping business. Based on a survey questionnaire sent to tanker and /or bulk maritime companies this study aims to investigate CSR and sustainability configurations, as they have been shaped in the light of United Nations 2030 Agenda. Developed hypotheses are tested using Pearson chi-square independence test and Spearman's correlation coefficient measure. Findings illustrate CSR as a strategic management tool to integrate sustainability challenges. Thereafter, the integrated management system (IMS) approach is, highly, indicated as the most effective business model to address sustainability into maritime operations. Though, the lack of a non-legally binding CSR regime is not found to influence companies' decision to adopt CSR.

\section{Keywords}

Ocean governance, UN's 2030 Agenda, corporate social responsibility, sustainable maritime transport, integrated management systems 


\section{Introduction}

The recognition and acceptance of shipping as major carrier of world trade is indisputable with figures showing that more than $90 \%$ of global goods movement is done by sea (Shi 2016). Although seaborne transport has always been considered as the most efficient and environmental friendly transportation mode, though, it has always been the subject of continuous and strict regulations (United Nations 2017). The reason is that maritime transportation refers to an inherently risky business that impacts the environment, the society and the economy as well. As example, shipping generates almost $3 \%$ and $15 \%$ of total $\mathrm{CO}_{2}$ and $\mathrm{NO}_{\mathrm{x}}$ emissions, respectively (Gjølberg et al. 2017). Moreover, working at sea has always been a hazardous occupation, bearing several risks to seamen (i.e. occupational accidents, fatigue, ergonomic risks etc.), the ship (i.e. loss of vessel from collision, structural damage) and the cargo (i.e. cargo partial damage or total loss) (Baker et al. 2002). And despite the several regulatory and political efforts to eliminate industry's adverse impacts, seaborne transportation continues to produce negative externalities. As a result, several initiatives and cooperation amongst various stakeholders, organizations and regulatory bodies (i.e. IMO, European Union, Flag Administrations, Port States, P\&I Clubs, Classification Societies, industry's Associations etc.) have been formed throughout shipping's long history (Kristiansen 2013).

Undoubtedly, those who deal with the operation and management of ships have always had the primal responsibility in ensuring and promoting the seaworthiness of their vessels. Nevertheless, the complicated nature of shipping (ships are readily transferable assets between owners, flags, class societies, trading areas, charterers and insurers) complicates the situation and bears several reverses in preserving a seaworthy fleet (Donaldson 1994). Therefore, the need to form and set the foundations of a legal maritime governance framework gave rise to the United Nations Convention on the Law of the Seas (UNCLOS). Such an act provides the first fundamental aspect and principal regulatory framework to confirm sovereign rights of States and also creates their obligations with respect to ocean governance (Morell 1992). In broad terms, ocean governance encompasses the efforts (policies, regulations, directives) of various actors (i.e. Flag Administrations, Port States etc.) to regulate oceans' use ensuring, thus, that all their users obey and comply with applicable statutory health, safety and environmental legislation (Friedheim 1999). In recent decades, increasing oceans' use, along with growing environmental, social and climate change concerns have, unavoidably, contributed to the establishment of an ocean governance system envisioned and ruled by sustainable development principles (Ehlers 2016; Dooley and Gullickson 1995). United Nations 2030 Agenda represents a remarkable recent undertaking in fostering sustainable development under its three dimensions (economic, social and environmental), with such a venture bearing implications to the maritime sector (United Nations 2017).

Similar to sustainable development trends, the concept of CSR has been, lately, emerged in the business setting and there are many arguments, from the public and private sector, to foster its positive contribution to the society and environment as well. Meanwhile, a lot of controversy has been developed for the social character of business and the way it can contribute to sustainable development (Prizing-Jorgensen and Farrag, 2010). The maritime industry could not have remained unaffected by such trends. The IMO, at the Symposium on a Sustainable Maritime Transportation System, held on September 2013, stressed out the need to consider sustainability principles across various aspects of shipping operations. Additionally, IMO expressed its desire and commitment to introduce and establish the concept of a sustainable maritime transportation system reinforcing, thus, the contribution of shipping to the achievement of global Sustainable Development Goals (SDGs) (Sekimizu 2012). Though, a notable highlight of such IMO's strategic position was the emphasis placed by the Organization on the belief that, amongst our drives for a sustainable shipping industry, 
we should "inter alia anchoring the vision of sustainable development into "Corporate Social Responsibility" (Sekimizu 2012:22). Such a standpoint is expected to shape industry's approach to CSR and sustainability. Similarly, at European level, the establishment of the European Sustainable Shipping Forum (ESSF), in September 2013, commended European Union's coherent initiative to establish and promote a sustainable European maritime industry, founded on the three pillars of sustainable development approach (EMSA 2019).

Further to the application of UN 2030 Agenda and SDGs in the maritime industry, this paper investigates insights over the relationship between corporate social responsibility and sustainable development, as perceived and experienced by shipping companies operating in the dry and tanker maritime sector. By explicitly surveying the angle from which shipping companies view associations and interactions between CSR and sustainability, this study seeks to add to existing knowledge by discussing a cohesive framework to distinguish and relate the concepts of CSR and sustainable development in the maritime sector. Secondly, by broadening industry's knowledge into these subjects, we aim to further contribute to the conception of effective CSR and sustainability instruments and management models across the maritime regime, so as to allow policy makers, regulators and shipping companies to chart a more sustainable maritime course.

\section{Background}

Over the last decades, the concepts of sustainable development and Corporate Social Responsibility have increasingly attracted the attention of scientists, business and intergovernmental actors. It was in the early 1970s, when the damaging environmental effect of economic growth and the, subsequent, detrimental influence on society's welfare were highlighted in the United Nations Conference on the Human Environment, held in Stockholm. The devastating approach that our world has had on economic development was further emphasized at the UN Conference on Environment and Development, in 1992, held in Rio de Janeiro (also referred to as the Earth Summit) (Imperatives 1987). Ten years later, in 2002, during the World Summit on Sustainable Development, held in Johannesburg, the obvious focus was to go beyond the short Rio Declaration and embrace a comprehensive action programme on sustainable development. Moreover, the concept of sustainable development attracted further attention at the UN Conference on Sustainable Development held in Rio de Janeiro, in 2012 (Chakraborty 2015). Some years later, on September 2015, the 2030 Agenda on Sustainable Development adopted at United Nations Headquarters and signified the contemporary historic development in promoting a sustainable future for our planet. As such, the 2030 Agenda and the 17 incorporated Goals, along with 169 associated targets, were widely accepted by all member countries and constitute a, universally, binding regulatory instrument (Nilsson et al. 2016).

Among the various existing approaches, the most prevailing term used to define sustainable development refers to: "the development that meets the needs of the present generation without compromising the ability of future generations to meet their own needs" (Imperatives 1987:41). However, regardless its definition, the fundamental argument of sustainable development is that the economic, social and environmental systems should be examined and treated as an integrated function and all of its components to be given equal importance (frequently termed as 'the triple bottom line' approach) (Elkington 1994). Equally to sustainability trends, the concept of corporate social responsibility has become increasingly important in the international business arena. Over the past few decades, CSR has become more and more 
popular in modern enterprises. Globalization, growing environmental sensitivity and social problems, as a result of rapid economic development, have placed CSR at the forefront of corporate strategy (Lund-Thomsen et al. 2016). Although there is no statutory universal standard and a commonly used definition on CSR, review from literature argues that it is commonly perceived as the attempt of companies to balance their social and environmental concerns with their economic objectives (Lekakou et al. 2016; Lee et al. 2016).

Reviewing the literature with regards to the interactions of sustainable development and corporate social responsibility has resulted to several approaches and interpretations of their meaning and association. In one perspective CSR is referred as a stakeholder issue that focuses mainly on managing stakeholder relationships (Maignan et al. 2005). Other studies treat CSR as a corporate managerial orientation that relates and integrates issues such as, ethics, transparency, stakeholder dialogue and sustainability principles (Maon et al. 2010). Furthermore, other researchers describe sustainable development and CSR as two synonymous concepts, which depict companies' desire to address their social and environmental challenges. In another perspective, CSR is defined as a corporate strategy to achieve profitability, while at the same time maintaining a balance among business ethics, environmental commitment, stakeholder engagement and society welfare (Ebner and Baumgartner 2006). Investigating further the association between CSR and sustainable development, CSR has been mostly regarded as a managerial approach and business tool for the private sector in dealing with sustainability challenges (McAdam and Leonard 2003). Thus, although CSR has been, frequently, termed as the social dimension of sustainable development, it has been, currently and commonly, recognized as a business model that assists enterprises to integrate sustainable development mandates into their corporate strategy dealing, thus, with their economic, environmental and social needs in depth (Behringer and Szegedi 2016). Such approach is also denoted as the corporate orientation of sustainability, often termed as corporate sustainability, and differentiates itself from the former meaning given to CSR concept, namely, its consideration as the social strand of sustainable development (Ebner and Baumgartner 2006).

As can be inferred from the up to now discussion, there is an abundance of historic events, intellectual approaches and practical attitudes to conceptualize and frame CSR and sustainability notions. However, framing our analysis to the maritime context, it is worth stressing that United Nations 2030 Agenda and incorporated 17 SDGs came to strengthen even more sustainability requirements and, subsequently, lend CSR with a further attribute and approach on the role that has to play in achieving sustainable maritime transport (United Nations Reflections on Social Accountability 2013). Further to such case, on February 2013, the director of the Representational Office of United Nations Industrial Development Organization (UNIDO), Mr. Christophe Yvetot, during the United Nations Industrial Development Organization Multi-Stakeholder Forum on CSR, stated: "SDGs are about achieving development goals from an economic, social and environmental perspective. In this view, we can think about CSR as a way to implement these goals at the level of enterprises." (UNIDO 2013:1). Analyzing further such United Nations standpoint, it has been obvious that there is a profound interest and vision to link CSR with sustainability and, in particular, employ CSR as a mean to achieve UN Sustainable Development Goals.

It has been noticeable so far that, equally to other industries, CSR and sustainable development have been gradually taking a prominent place in the maritime business. Analysing relevant IMO's and European Union viewpoints and taking into account the growing concern of international actors on CSR and sustainability matters, it can be concluded that there is an emerging trend across the shipping sector to employ CSR as a mean to promote and diffuse sustainability (Madrakhimova 2013). At a policy level, incorporation and dissemination of sustainability and CSR tendencies into IMO's and European Union's vision and regulatory mechanisms reveals their strong commitment to achieve a sustainable and 
socially responsible industry remaining, thus, fully harmonized with United Nations' mandates (Szegedi 2010). However, with the exception of the container and cruise sector, CSR in the shipping industry is still a voluntary undertaking that has been, customarily, associated with maritime safety, environmental and quality management matters (Madrakhimova 2013). Similarly, further to a study carried out in the Baltic Sea maritime sector, it was revealed that maritime companies understand CSR as a health, safety and environmental compliance issue that serves as a vehicle to improve health, safety, environmental performance and company's reputation. According to the same study, engagement with CSR was not viewed as a strategic priority and a mean to benefit the company in the long-term from several perspectives (economic efficiency, social image, better stakeholder management, reduced corporate risk etc.) (Kunnaala and Viertola 2014).

Considering the latest United Nations, IMO and EU initiatives to unveil CSR as the vehicle to sustainable development, it is assumed that little has been known so far on the relationship between CSR and sustainable development and specifically, the role of CSR in achieving sustainability in global shipping. Such deductions, call for further research into the investigation of maritime industry (dry and tanker shipping sector) insights over the association between CSR and sustainable development. Generating such knowledge will assist policy and regulatory entities, along with other stakeholders involved into ship management activities to appreciate present situation, redefine their theoretical approach and identify effective business models so as to accomplish sustainability throughout maritime operations.

\subsection{Hypotheses development}

\subsubsection{CSR as an integrated and beyond regulatory compliance notion}

Corporate social responsibility refers to a multidimensional concept and engagement with its various theoretical and practical crossing points has given rise to numerous elucidations and versions of that term (Van Marrewijk 2003). Definitely, it is an evolving conception, which has progressed over the past century and, moreover, has significantly impacted past and present business culture and actions (Khan et al. 2012). During the 1950s and the 1960s it was mostly identified as companies' obligations towards society and emphasized their responsibility to safeguard welfare of employees and society's in general (Davis 1960). Over that period, a wider recognition of CSR was closely related to philanthropic and charitable activities (Murphy 1978). Conversely, opposing voices such as Friedman's (2007) standpoint recognized businesses as a profit making organization, with a sole responsibility to maximize economic value and shares to their shareholders. In line Friedman's (2007) approximation, CSR is also identified as "an evolving concept that managers are adopting as an alternative to the traditional growth and profit-maximization model" (Wilson 2013:1). However, maintaining solely legitimate compliance and profit maximization is not adequate to establish a socially responsible business (McWilliams and Siegel 2001). During the 1980s and the 1990s, growing environmental crisis and the need to consider stakeholder concerns into business processes have shifted the rationale of CSR towards social and environmental topics (Carroll 2000). Recently, emerging and alternative approaches to CSR have appeared and established it as an integrated three-dimensional approach (economic, social and environmental) (Dewangga et al. 2008), which maintains a voluntary and beyond regulatory compliance character (Bowen and Haire 1975). The voluntary and beyond regulatory compliance CSR aspects have been also stressed by Bowen and Haire (1975) and suggest that enterprises, operating within a wider social and natural system, should go one step further their typical statutory responsibilities and reflect ethical and moral perspectives in their operations. 
Coming to the sustainability issue, protecting our natural environment and preserving our natural ecosystem lies in the core of sustainable development concept (Hugeand and Waas 2011). Despite the several intellectual approaches and evolving processes, sustainable development was primarily introduced and established in an attempt to halt ecological degradation and deal with negative impacts deriving by unbridled economic development (Reid 2005). However, it was during the 1990s when sustainable development was coined as an integrated notion requiring business to be precautionary and balance the economic pursuits with social and environmental risks and uncertainties, the so called 'triple bottom line' approach (Elkington 1994). Nowadays, there is a general consensus that sustainable development has to be seen and achieved in a combined manner. Thus, such unified and continuous process has been acknowledged as the well-adjusted achievement of sustainability principles and objectives (Gibson et al. 2005). In this line, UN's 2030 Agenda on Sustainable Development aimed at addressing sustainability challenges in an integrated manner and committed in achieving sustainable development in its three dimensions (economic, social and environmental) (Nam 2015). Under such developments, CSR can serve as the vehicle to achieve sustainability objectives (Dey and Sircar 2012). Hence, CSR is treated as a business model and strategic management tool that drives business performance and sustainable function through cost and risk reduction, profit maximization, regulatory compliance, ethical behaviour, stakeholder engagement etc (Kurucz et al. 2008). Such a homogeneous, integrated and uniform tactic that, furthermore, considers company's economic, social and environmental aspects sets, by definition, CSR principles in the heart of corporate strategy (Rochlin et al. 2005). An underlying feature of this process is that embedding CSR into business strategy, ultimately, implants sustainability dimensions (economic, social and environmental) across business operations and, thus, leads to the indirect adoption of sustainability values at strategic level (Ganescu 2012). Consequently, sustainability is placed under the auspices of CSR and is attempted through CSR strategy and business model (Teece 2010).

Such managerial understanding on the relationship between CSR and sustainable development appears to be consistent with latest IMO vision, which pursues the achievement of a sustainable maritime transportation system framed into CSR principles (Sekimizu 2012). Within the European Union framework, the European Sustainable Shipping Forum (ESSF), created on September 2013, aims at assisting the European Commission in implementing programs and initiatives with regards to maritime transport sustainability. Similar to United Nations and IMO standpoint, European Commission fosters to strengthen the development of a sustainable European shipping industry in an integrated manner and founded into a CSR values (Van Leeuwen 2015). Such mutuality and interdependency between CSR and sustainability in European shipping has been further reinforced by other maritime stakeholders. In particular, the Norwegian Shipowners' Association has explored and presented shipping potential contributions to SDGs. In their CSR report, UN Global Compact's Ten Principles are employed and a framework to integrate Sustainable Development Goals into maritime operations has been drafted. As such, CSR is recognized as a management strategy, which should be seen by maritime companies as an opportunity to align their policies and business operating models with latest sustainability goals (Norwegian Shipowners' Association 2019). Hence, it is believed that companies that understand CSR as a strategic and beyond regulatory compliance business approach, will be more inclined to recognize and deal with sustainability as a notion embraced under the auspices of a CSR policy / programme. As a result it is hypothesized that:

$H_{1}$ : Embedding sustainability into company's CSR policy is closely related to CSR identification as an integrated and beyond regulatory compliance notion. 


\subsubsection{CSR as an integrated business model to manage sustainability}

Organizations operate in an evolving environment with their business performance and continuity to be significantly governed by factors, such as globalization trends, technological advances, regulatory changes, societal evolutions and ecosystem configuration (Giesen et al. 2010). Enduring and progressing in such competitive surroundings companies need to analyse faced challenges, understand their strengths and limitations, define their position and find their orientation (Casadesus-Masanell and Ricart 2010). Such process and organization's philosophy has been frequently termed as strategy or strategic thinking. As such, strategy notion encompasses an organization's goals and objectives and the actions to be taken in order to achieve them, along with the allocation and balancing of required resources (Chandler 1962). There is a distinction though between strategy and activity term. Strategy lies on the top level of an enterprise and refers to the motivating and creative force of an activity (Porter 1996). As such, an activity is the subsequent result of a strategic thinking (Osterwalder 2004). Hence, a link is needed in order to diffuse the strategy to all layers of an organization and shape processes and activities in a way that will serve corporate objectives. Such link has been frequently termed as a business model (Mustafa and Werthner 2011). Although the business model conception shares many characteristics, however, in broad terms, it reflects the way an organization operates (Markides 2013). A business model is an important tool for senior management in order to spread strategic directions across the organization and reach, as such, desired objectives (Venkatramann and Henderson 1998). Moreover, it refers to the underlying logic and rationale behind all established organization's processes used for profit generation, risk elimination, management of relationships and, thus, value creation (Petrovic et al. 2001). In that sense, there is an obvious linkage between strategy and business model, which is denatured into company's detailed procedures used to deliver management objectives (Harreld et al. 2007).

Effective functioning of a business model requires the development of specific processes and procedures, reflective to the organization's needs and operating aspects (Pardy and Andrews 2009). As previously mentioned firm's viability and development requires several aspects and challenges to be considered, depending on the business nature, scope and strategic objectives (Raišienè 2011). Hence, there are several industry Standards and statutory Codes, such as ISO9001 (quality management), IS014001 (environmental management), OHSAS18001 (health \& safety management) aiming to set the principles and operating framework for specific company's procedures to be developed (Oskarsson and Von Malmborg 2005). It has been popular though in modern business practices to integrate the elements of different industry Standards and statutory regulation in a uniform management pattern, termed an integrated management system (IMS) (McDonald et al. 2003). Although elements of such Standards can function as standalone, however, the IMS approach addresses company's challenges and stakeholder requirements in a systematic, flexible and coordinated manner avoiding, thus, duplication and waste of resources (Wright 2000). With regards to corporate social responsibility, as stressed above, adoption of CSR principles starts at corporate level and is related with organization's strategy and overall approach to do business (Weber 2008). Integrating CSR into business strategic objectives requires the conception of a business model that will foster and achieve its driving principles (Deming 2018). The integrated management system approach provides a systematic method to translate company's strategic objectives and goals at all organizational levels and business processes. Thus, prescribed procedures can be developed reflecting organization's challenges, stakeholders' expectations and performance indicators (Asif et al. 2013). Rightly, embracing the principles of voluntary industry standards, each one dealing with a plethora of safety, social, economic and environmental regulations, eliminates complexity, enriches and standardizes company's management alternatives and places various safeguards against several risks (Abrahamsson et al. 2010). 
Sustainable Development Goals came to stress some of the world's greatest challenges. Governments have already anticipated compliance from the private sector, which is considered to be a vital factor for the success of such ambitious global venture (Sachs 2012). Shipping companies will need to see themselves as supporters and assist governments to achieve their goals. In that scene, CSR can hold a prominent place in assisting the maritime sector to align its strategy with international and European sustainability mandates contributing, thus, to the fulfillment United Nations Sustainable Development Goals (Toffel et al. 2003). Integrating and embedding CSR concept into maritime operations can lend shipping companies with a strategic management tool that will assist them to go one step further and fulfil IMO's and European Commission sustainability directives. However, in order such attempt to be productive it has to constitute part of core business strategy and objectives which, furthermore, is reproduced to an integrated management system model (Poulovassilis and Meidanis 2013). Therefore, understanding CSR as a strategic business model that integrates sustainability dimensions (environmental, social and economic,), is more likely to be accompanied by the adoption of the integrated management system approach, as a mean to accomplish company's objectives. It is consequently, hypothesized that:

$\mathrm{H}_{2}$ : Recognizing the integrated management system approach as the most effective tactic to achieve sustainability is closely related to CSR understanding as a business model and strategic management tool.

\subsubsection{CSR, voluntarism and the lack of a maritime regulatory framework}

CSR concept has been redefined and incorporated into the policy and tactic agenda of global organizations. The International Labour Organization (ILO) has approached CSR as an integrated process, whereby companies take into consideration their impact on society, environment and affected stakeholders (ILO 2007). The European Commission (EC) defined CSR as a "concept whereby companies integrate social and environmental concerns in their business operations and in their interaction with their stakeholders on a voluntary basis" (Pike et al. 2010:6). Such approach clearly considers CSR as a mean to deal with social and environmental challenges in a legitimate manner, while sharing the feature of voluntarism (European Commission 2011). Depending on the sector and business scope, private and stateowned corporations are obliged to conform to applicable legislation, which relates to the observance of several environmental, social and financial legislation (Theilkemeier et al. 2010). In our era, United Nation's Sustainable Development Goals have set a global and binding legal framework for the private and public actors to face associated social, economic and environmental issues. Although, such initiative is politically driven, though, it seeks to promote the socially responsible character of the private sector as a major contributor and facilitator to the achievement of sustainable development (Stafford-Smith et al. 2017).

Over time, it has been observed that business have, customarily, been involved in CSR activities, although, same were not consciously perceived as CSR actions at that time (Theilkemeier et al. 2010). However, despite the growing number of norms, instruments, codes of conduct and other guidelines developed by UN or other non-governmental organizations and industry bodies, they do not constitute a legally binding framework to CSR implementation (Bantekas 2004). Accordingly, they function on a voluntary and beyond regulatory compliance basis aiming, mostly, at stakeholders' management and integration (Reinhardt and Stavins 2010). Further to that, Alavi et al. (2016) outlines CSR as a voluntary self-regulatory set of principles and guidelines, which, furthermore, is transmitted to the private sector through nonbinding treaties. Under such approach, self-regulation differentiates itself from statutory regulation in the sense that it maintains a voluntary nature. Amongst numerous developed guidelines, recommendations, standards and set of principles, OECD Guidelines and UN Global Compact relate to some of the most influential governmental instruments destined to address CSR in business operations. However, along with other formulated industry standards, such as 
AA1000-Principles Standard, ISO 26001CSR Standard and SA8000 Social Accountability, they all maintain non-legally binding scope and content (Bantekas 2004).

The emergence and gradual diffusion of CSR in shipping is a reality and, as such, further industry's engagement is believed to positively supplement and fill the gaps of the international maritime regime (Coady et al. 2013). However, as was addressed in the previous discussion, CSR in shipping is, mainly, practiced by the container and cruise line companies and is, mostly, encountered through the development of safety, health and environmental procedures and not as an integrated strategic vision (Pawlik et al. 2012). As Progoulaki and Roe (2011) suggest CSR in shipping is seen as a system to enhance compliance with environmental legislation. Moreover, customers of maritime companies (i.e. shippers, suppliers, charterers etc) have been primarily concerned with cost efficiency and view CSR as secondary aspect of the shipping service (Fafaliou et al. 2006). Since CSR is viewed as a voluntary system and there is still no legally binding regulatory regime to enforce CSR, most shipping companies are not keen to exceed mandatory legislation and, thus, increase their operating expenses (Kunnaala et al. 2013). Moreover, the shipping industry has been, typically, a highly regulated industry with shipping companies seeking primary compliance with statutory health, safety and environmental standards (Acciaro 2014). At policy level, CSR in shipping has arisen quite recently. Specifically, encouraging shipping companies to engage with CSR, as a mean to improve efficiency and contribute to global sustainability, firstly appeared in the outcome of the UN 2030 Agenda and SDGs (Sekimizu 2012; Norwegian Shipowners' Association 2019; UNIDO 2013). In that sense, the lack of a CSR maritime regulatory regime is expected to be a deterring and influential factor for such late engagement of CSR principles by shipping companies. In that way, it is hypothesized that:

$\mathrm{H}_{3}$ : Lagging engagement of CSR in shipping is closely related to the absence of a CSR maritime regulatory framework.

\section{Materials and methods}

\section{Research design}

The aim of this study is to investigate present interactions and the contributory role of CSR to the achievement of sustainable maritime development. Further to that, the positivist position is regarded as the most appropriate research paradigm to suit this study aim. In brief, the positivist approach requires the review of existing theory and develops new hypotheses to be tested during the research process (Burns and Bursn 2000). To do so, a quantitative research approach is considered to be compatible with such a pursuit. Such approach requires the collection of numerical data with the aim to examine relationships between set variables, verifying, thus, research hypotheses developed by conducted literature review (deductive research approach) (Neuman 2013). Further to our research aims, participating companies were identified as those having undertaken the technical management of dry bulk carriers and/or tanker vessels. The management of other ship types (i.e. containerships or passenger vessels) was also permissible. However, it was obligatory that, along with other ship types, companies shall manage at least dry bulk carriers and/or tanker vessels. Such a criterion derives from our desire to investigate this particular maritime sector and fill the gap from the, relatively, limited research in that field. A total of 50 companies, based in 14 countries globally, participated. 


\section{Data collection method}

Quantitative data collected via a self-administered electronic questionnaire survey. Investigative questions and variables were designed based on the gaps identified by literature review, particular areas of study interest and coherence to the formulated hypotheses we seek to verify. The range of respondents was based on the criterion to approach employees working in departments that are called to implement operating policies and procedures and have, either directly or indirectly, become recipients of corporate strategy and top management decisions (Dooley and Gullickson 1995). Therefore, electronic questionnaires were sent via email to maritime professionals held higher positions in one of the following departments: operations, QHSE, technical, human resources, and management/accounting department. In that respect, they are considered to have adequate knowledge and experience to answer our questions and, as such, address, their organizations' perceptions, practices and attitude on CSR and sustainability issues.

\section{Variables}

A number of variables were introduced in order to investigate perceptions over the relationship between CSR and sustainability. The selection of such variables was performed with the criterion to choose those variables that will better serve our research objective, inform our developed hypotheses and, therefore, illuminate perceived linkages and conformations between CSR and sustainable development. Research variables are categorical, measured on a nominal and ordinal scale. Furthermore, they are presented as statements and respondents are asked to indicate their level of agreement on a five-point Likert (strongly agree to strongly disagree) and Guttman (yes/l am not sure/no), scaling (Bezerra et al. 1998). A summary of variables incorporated in our study are presented in Table 1.

\section{Data analysis method}

In meeting the objective of this study, gathered data are analysed by employing descriptive and inferential statistics. Hypotheses 1 and 3 are tested using Pearson's chi-square independence test and contingency coefficient measure. On a conceptual basis, chi-square test determines whether a statistically significant relationship between variables exists or not, with $a=0.05$ being the level of significance. When the $p$-value $<a$, then null hypothesis is rejected (Field et al. 2012). In conjunction with chi square independence test, contingency coefficient $(C)$ measure is also used to determine the strength of association between variables. $\mathrm{C}$ values range between -1 to 1 . Values close to 1 indicate a strong positive relationship, while values close to -1 indicate a perfect negative association. 0 values indicate no relationship and values close to 0 represent weaker associations (Tan et al. 2004). Hypothesis 2 is tested by employing Spearman's correlation coefficient measure. This statistical measure is appropriate for categorical variables, such as those used in hypothesis 2 , measured on an ordinal scale. Further to Spearman, a statistically significant association is said to occur between variables, when the $p$-value is less than 0.05 (with $a=0.05$, being the level of significance) (Myers and Sirois 2004). Moreover, obtained correlation coefficient (Rs) values are important in order to identify the strength of association between the two selected variables. Rs values close to 1 imply a strong positive relationship between variables. Contrary, Rs values close to -1 signify a perfect negative association. 0 values mean that no relationship has been identified between selected variables (Rebekić et al. 2015). The Statistical Package for Social Sciences (SPSS) version 25 for Windows is used for conducting our statistical analysis. 
Table 1 below presents the hypotheses and corresponding variables incorporated in our study, along with respective data analysis method.

Table 1. Independent and Dependent Variables and Corresponding Hypotheses

\begin{tabular}{|c|c|c|c|}
\hline Alternative Hypothesis & Independent Variable & Dependent Variable & $\begin{array}{l}\text { Testing } \\
\text { Method }\end{array}$ \\
\hline $\begin{array}{l}\mathrm{H}_{1} \text { : Embedding sustainability into company's CSR policy is closely related } \\
\text { to CSR identification as an integrated and beyond regulatory compliance } \\
\text { notion. }\end{array}$ & $\begin{array}{l}\text { CSR identification as an } \\
\text { integrated and beyond } \\
\text { regulatory compliance notion. } \\
\text { (Ordinal) }\end{array}$ & $\begin{array}{l}\text { Sustainability embedding } \\
\text { into company's CSR policy. } \\
\text { (Nominal) }\end{array}$ & $\begin{array}{l}\text { Chi-square } \\
\text { test of } \\
\text { independence }\end{array}$ \\
\hline $\begin{array}{l}\mathrm{H}_{2} \text { : Recognizing the integrated management system approach as the } \\
\text { most effective tactic to achieve sustainability is closely related to CSR } \\
\text { understanding as a business model and strategic management tool. }\end{array}$ & $\begin{array}{l}\text { CSR understanding as a } \\
\text { business model and strategic } \\
\text { management tool. (Ordinal) }\end{array}$ & $\begin{array}{l}\text { The integrated management } \\
\text { system approach in } \\
\text { achieving sustainability. } \\
\text { (Ordinal) }\end{array}$ & $\begin{array}{l}\text { Spearman's } \\
\text { correlation } \\
\text { coefficient }\end{array}$ \\
\hline $\begin{array}{l}\mathrm{H}_{3} \text { : Lagging engagement of CSR in shipping is closely related to the } \\
\text { absence of a CSR maritime regulatory framework. }\end{array}$ & $\begin{array}{l}\text { Lagging CSR engagement in } \\
\text { shipping. (Nominal) }\end{array}$ & $\begin{array}{l}\text { Absence of a CSR maritime } \\
\text { regulatory framework. } \\
\text { (Nominal) }\end{array}$ & $\begin{array}{l}\text { Chi-square } \\
\text { test of } \\
\text { independence }\end{array}$ \\
\hline
\end{tabular}

\section{Results}

This section discusses the demographic characteristics of the respondents engaged in this study and provides an overview of their perspectives. Next, section 4.2 presents the results from hypotheses testing.

\subsection{Demographical data and descriptive statistics analysis}

A total of 50 maritime companies participated in the electronic questionnaire survey. With regards to their base country, 11 are based in Norway (22\%) and 10 in Greece (20\%). The remaining participants' base country is formed as follows: 7 in Denmark (14\%), 4 in Germany (8\%), 4 in Cyprus (8\%), 3 in Finland (6\%), 2 in Canada (4\%), 2 in Switzerland (4\%), 2 in The Netherlands (4\%), while the remaining 5 are based in countries such as Monaco, Turkey, Sweden, Belgium and Italy. 38 of respondents are males (76\%) with the remaining $12(24 \%)$ being females. Among all participants, $34 \%$ and $32 \%$ belong to the 41 to 50 and $51+$ age groups respectively. Moreover, $32(64 \%)$ and $6(12 \%)$ of them hold positions in the QHSE and human resources department correspondingly. Participants' age and working department figures imply a relatively high level of experience and sufficient exposure into their company's CSR and sustainability matters. Furthermore, 21 (42\%) and 17 (34\%) of participating companies manage a fleet that ranges between 1 to 20 ships and $61+$ respectively, while 5 (10\%) operate a fleet of 21 to 40 vessels. 29 companies (58\%) employee more than 251 staff (both at the office and ashore), while 4 (8\%) occupy 1 to 50 . Accordingly, occupied sea and shore staff size, along with number of ships under management, illustrate a medium to large companies' size. Interestingly, most of the participants (94\%) answered that they are personally aware of CSR theme, while $6 \%$ of the participants replied that they were not aware. Viewing such finding, in conjunction with the fact that 41 (82\%) of the companies have adopted CSR policy/principles in their ship management substantiates our literature review conclusions that, nowadays, CSR refers to a, progressively, expanding concept and practice in shipping (Sisteré 2013). 
A point worth mentioning is that although the majority of the companies have incorporated CSR principles (82\%), only 1 company (2\%) however, was found to have been officially certified against a CSR Standard (i.e. ISO26000, SA8000 etc.). Remarkably, $62 \%, 58 \%$ and $26 \%$ of companies have been officially certified against ISO14001 (environmental management), ISO 0001 (quality management) and OHSAS18001 (health and safety management) respectively. Similar to this finding, $72 \%$ utilizes an integrated health, safety and environmental report to measure and disseminate business performance, while $16 \%$ pick a dedicated annual CSR report option. Such finding mirrors our literature review conclusions, namely, that the shipping industry, mostly, identifies CSR with environmental, health and safety matters (Kunnaala and Viertola 2014). Moreover, such companies' stance could be, potentially, explained by the plethora of maritime regulations covering several social, health, safety and environmental aspects of shipping operations. Thus, achieving compliance against existing statutory and industry standards is considered as equally adequate to ensure a socially responsible and sustainable firm. Therefore, seeking certification against an additional official CSR Standard, measuring and reporting tool is, possibly, considered by shipping companies as pleonasm (Yuen and Lim 2016). Such result is also consistent with the study carried out at the Baltic Sea maritime sector and revealed that maritime companies, mostly, understand CSR and sustainability identical to health, safety and environmental compliance issues (Lund-Thomsen et al. 2016).

\subsection{Hypotheses testing results}

\section{Testing of hypothesis 1}

The statistical significance of hypothesis 1 was tested applying Pearson chi-square test of independence. Results show the existence of a statistically significant association between selected variables. Thus, at the level of significance $a=0.05$, companies that identify CSR as an integrated and beyond regulatory compliance notion are more likely to perceive sustainability embedded in company's CSR policy / programme. As such, the null hypothesis is rejected $\left(X^{2}(6)=17,714, p\right.$-value $\left.=0.007\right)$. Moreover, as per contingency coefficient $(C)$ measure, the estimated value is 0,511 . Such result implies the existence of a strong positive relationship between CSR understandings as an integrated and beyond regulatory compliance notion (independent variable) and sustainability recognition as part of company's CSR policy / programme (dependent variable) supporting, thus, the acceptance of the alternative hypothesis $H_{1}$. In that sense it is expected that the more CSR is understood as an integrated and beyond regulatory compliance notion, the more companies will be inclined to consider sustainability as a notion embedded into company's CSR policy / programme.

Table 2. Hypothesis 1: Application of chi-square test of independence

\begin{tabular}{|c|c|c|c|c|}
\hline Null Hypothesis & $\begin{array}{c}\mathrm{p}- \\
\text { value }\end{array}$ & $x^{2}$ & $\begin{array}{l}\text { Contingency } \\
\text { Coefficient (C) }\end{array}$ & $\begin{array}{c}\mathrm{H}^{0} \\
\text { Rejected } \\
(\mathrm{a}<0.05)\end{array}$ \\
\hline $\begin{array}{l}\mathrm{H}_{0} \text { : Embedding sustainability into company's CSR policy is not closely related to CSR identification as an } \\
\text { integrated and beyond regulatory compliance notion. }\end{array}$ & $0,007^{\star}$ & 17,714 & $0,511^{\star \star}$ & Yes \\
\hline
\end{tabular}

Notes: ${ }^{*} \mathrm{H}_{0}$ rejected at significance level $\mathrm{p}<0.05 .{ }^{* *}-1 \leq \mathrm{C} \leq 1,-1=$ perfect negative relationship, $0=$ No relationship, $1=$ perfect positive relationship 
Testing of hypothesis 2

We tested the statistical significance of hypothesis 2 by employing Spearman's correlation coefficient measure. Results imply that at the level of significance $a=0.05$, companies that perceive CSR as a business model and strategic management tool are more likely to recognize the integrated management system approach as the most effective management system to achieve sustainability. A statistically significant association has been identified leading, thus, to the rejection of the null hypothesis ( $p$-value $=0.001$ ). Furthermore, obtained correlation coefficient $(R s)$ value is 0,457 . Such result implies a positive association between identified variables confirming, thus, the acceptance of the alternative hypothesis $\mathrm{H}_{2}$. Under such result it is supported that raising CSR understanding as a business model and strategic management tool (independent variable) will stimulate the appreciation of the integrated management system approach as the most effective method to achieve sustainability (dependent variable).

Table 3. Hypothesis 2: Application of Spearman's correlation coefficient measure

\begin{tabular}{|c|c|c|c|}
\hline Null Hypothesis & $\begin{array}{l}\text { p- } \\
\text { value }\end{array}$ & $\begin{array}{c}\text { Spearman's } \\
\text { correlation } \\
\text { coefficient }\left(R_{s}\right)\end{array}$ & $\begin{array}{c}\mathrm{H}^{0} \\
\text { Rejected } \\
(\mathrm{a}<0.05)\end{array}$ \\
\hline $\begin{array}{l}\mathrm{H}_{0} \text { : Recognizing the integrated management system approach as the most effective tactic to achieve } \\
\text { sustainability is not closely related to CSR understanding as a business model and strategic management tool. }\end{array}$ & $0,001^{*}$ & $0,457^{\star \star}$ & Yes \\
\hline
\end{tabular}

Notes: ${ }^{*} H_{0}$ rejected at significance level $p<0.05 .{ }^{* \star}-1 \leq(R s) \leq 1,-1=$ perfect negative relationship, $0=$ No relationship, $1=$ perfect positive relationship

\section{Testing of hypothesis 3}

Due to the nature of hypothesis 3 variables (nominal), their statistical significance was tested using Pearson chi-square test of independence. As per results, the $p$-value is 0.995 , which is $>0.05$ (level of significance a). Further to that, no significant relationship has been identified between selected varibles leading, thus, to the retainment of null hypothesis $\left(X^{2}(4)=0.217, p\right.$-value $\left.=0.995\right)$. Such finding implies that the lack of a CSR maritime regulatory framework is not related to the retarded engagement of CSR in shipping. Likewise, as the assessed contingency coefficient (C) value found close to zero $(0,067)$, such result indicates the non-existence of an association between variables of hypothesis 3 . It is, therefore, assumed that the non-establishment of a CSR regulatory regime in shipping so far has not exercised any influence on the sector's interest to implement CSR.

Table 4. Hypothesis 3: Application of chi-square test of independence

\begin{tabular}{|c|c|c|c|c|}
\hline Null Hypothesis & $\begin{array}{c}\mathrm{p}- \\
\text { value }\end{array}$ & $x^{2}$ & $\begin{array}{l}\text { Contingency } \\
\text { Coefficient }(C)\end{array}$ & $\begin{array}{l}\mathrm{H}^{0} \text { Rejected } \\
(\mathrm{a}<0.05)\end{array}$ \\
\hline $\begin{array}{l}\mathrm{H}_{0} \text { : Lagging engagement of CSR in shipping is not closely related to the absence of a CSR } \\
\text { maritime regulatory framework. }\end{array}$ & $0,995^{\star}$ & 0,217 & $0,067^{\star *}$ & No \\
\hline
\end{tabular}

Notes: ${ }^{*} H_{0}$ rejected at significance level $p<0.05 .{ }^{* *}-1 \leq \mathrm{C} \leq 1,-1=$ perfect negative relationship, $0=$ No relationship, $1=$ perfect positive relationship 


\section{Discussion}

2 out of 3 developed hypotheses of this study have been verified $\left(H_{1}\right.$ and $\left.H_{2}\right)$, while 1 has been rejected $\left(H_{3}\right)$. To a large extent, research results found to be consistent with theoretical assumptions made during the literature review and identify CSR as an integrated and beyond regulatory compliance notion that embeds sustainability aspects (Giovannoni and Fabietti 2013). Similarly, findings are coined with analogous studies that consider the integrated management system approach as the most effective business model to achieve sustainability.

\section{CSR as an integrated and beyond regulatory compliance notion}

Confirmation of hypothesis $\mathrm{H}_{1}$ implies that perceiving CSR as an integrated and beyond regulatory compliance notion is significantly associated with the consideration of sustainability as part of company's CSR policy. The fact that CSR has been seen as an integrated voluntary business approach has also been emphasized in studies of Behringer and Szegedi (2016), Ebner and Baumgartner (2006) and Wilson (2003) that have, further, recognized CSR as a strategic and managerial approach to deal with social, economic and environmental challenges. As per study results, sustainability has been identified as a concept resting under the auspices of a CSR business model and, thus, appears to be consistent with previous studies' findings (Dey and Sircar 2012; Kurucz et al. 2008; Ganescu 2012). Such point sounds logical supposing that further broadening our awareness on CSR concept and implementation aspects will, inevitably, lead companies to the assumption that the multilateral aspects of sustainability should be integrated into a business model, governed by CSR principles. In the maritime context, such finding is also aligned with IMO's and European Union latest strategies, which aim to promote the establishment of a sustainable maritime transportation system, founded on CSR principles (Sekimizu 2012; EMSA 2019). Furthermore, and being fully in line with other industry studies, the identified strong positive association between variables of hypothesis $\mathrm{H}_{1}$ affirms that the maritime industry considers CSR as the vehicle to sustainability (Teece 2010; Kurucz et al. 2008). Such entails that the more CSR is understood as an integrated and beyond regulatory compliance notion, the more sustainability will be attempted through the institution of a CSR corporate strategy. A plausible explanation lies on the profound tendency to achieve sustainability in the private sector, through the establishment of a CSR business philosophy. Obviously, as stressed previously, such position has been greatly endorsed through IMO's vision for a sustainable maritime transportation system and, thus, appears to have significantly shaped the shipping industry (Sekimizu 2012).

\section{CSR as an integrated business model to manage sustainability}

Investigating further the relationship between CSR and sustainable development, study results illustrate that the integrated management system approach refers to the preferred method to achieve sustainable shipping operations, a fact which is further supported by literature review assumptions (Abrahamsson et al. 2010; McDonald et al. 2003). Specifically, and in support of previous argumentation, evidence from testing hypothesis $\mathrm{H}_{2}$ affirms our earlier assumption, namely, that perception of CSR as a business model and strategic management tool is positively related to the recognition of the integrated management system approach as the most effective management system to achieve sustainability. This is, potentially, explained by the complex and multifaceted challenges that shipping has to deal today. In that sense, understanding and placing CSR at the forefront of corporate strategy drives, inadvertently, the organization 
in quest of a business model that will be governed by CSR principles. The integrated management system approach turns out to be a viable solution in such a pursuit of sustainability management. Therefore, it is ascertained a linear relationship between CSR strategy, CSR business model and integrated management system. Similarly, such findings are in line with IMO's, United Nations and other shipping Associations viewpoint on the role of CSR as a business model facilitator and contributor to the achievement sustainable shipping (Sekimizu 2012; Norwegian Shipowners' Association 2019; UNIDO 2013). Such deductions are further supported by the strong identified relationship between variables of hypothesis $\mathrm{H}_{2}$. Apparently, it is implied that the more CSR is diffused and understood as a business model, the more the integrated management system approach will be considered as the most effective mean to achieve sustainability (Asif et al. 2013; Jørgensen et al. 2006).

\section{CSR, voluntarism and the lack of a maritime regulatory framework}

On the basis of research results, hypothesis 3 was not confirmed and, hence, results were not found to be consistent with theoretical assumptions made during hypothesis development stages. Therefore, the fact that there has not been an established regulatory CSR regime in shipping yet, has not exercised any influence so far on companies' decision to adopt CSR. A plausible explanation for this finding may be attributed to the fact that the shipping industry has always been a highly regulated industry (Donaldson 1994). According to Yuen and Lim (2016) study high regulatory standards refer to a significant barrier and deterring factor to CSR implementation in shipping. Indeed, existing regulatory regime has placed a heavy burden, in terms of compliance efforts and associated cost, which discourages CSR engagement (Campbell 2007). Additionally, the relatively recent application of CSR in shipping has, potentially, reflected the industry's low maturity to appreciate CSR long term benefits. Such a fact viewed in conjunction with the voluntary and beyond regulatory compliance understanding of CSR can, reasonably, explain shipping lagging involvement (Madrakhimova 2013). Moreover, the almost absent association between CSR engagement and the lack of a relevant maritime regulatory regime is further supported by the close to zero contingency coefficient value $(C=0,067)$. In the same way, it is worth mentioning that that although the majority of shipping companies have adopted a CSR policy (82\%), though, only 1 out of 50 participating companies found to be officially certified against a CSR standard. Such a low interest for official CSR certification is also consistent with above theoretical framework, which suggests that CSR is mostly regarded as a managerial approach undertaken voluntarily (Ebner and Baumgartner 2006; Behringer and Szegedi 2016). Thereby, nonverification of hypothesis 3 indicates that CSR adoption by shipping companies' is unrelated to the existence or not of a binding CSR regulatory regime.

\section{Study implications}

In the light of United Nations 2030 Agenda and with the look turned to the new reality, as has been shaped by the introduction of SDGs in shipping, the main aim of this study was to investigate and reframe the relationship between CSR and sustainability in the tanker and dry bulk maritime sector. In the aftermath of such trends and regulatory developments, findings have notable implications to knowledge, policy makers, regulators and ship managers setting, thus, also the foundations for future study directions. 
Firstly, this study advances our insight on the conception and association between CSR and sustainable development, in the shipping industry. As a result, CSR is seen as managerial approach taken at strategic level, which places under its umbrella current sustainability matters. Furthermore, in order to achieve sustainability goals, the adoption of an integrated management system approach, founded on CSR principles, is considered identical. Notably, the non-existence of a CSR regulatory regime does not exercise any influence to the adoption of CSR and is not rendered responsible for late CSR adoption in the maritime industry. Secondly, from a regulatory and policy perspective, an underlying implication for policy makers and regulators, which stems from our framing of CSR as a managerial approach to sustainability, is the deterrence of the idea to create a new mandatory CSR regulatory regime (Lund-Thomsen et al. 2016). As such, another mandatory regulatory CSR Standard is, potentially, considered by shipping companies as pleonasm (Yuen and Lim 2016). Such deduction may direct the focus and efforts of policy makers and regulators in areas of education, training and establishment of a common language on CSR and sustainability implementation, rather than creating and enforcing a new mandatory CSR regulatory regime. Thirdly, being mindful about the study findings, ship managers can broaden their awareness and professional judgement on the interactions between CSR and sustainable development and, as such, transfer this knowledge in their actual operations. Appreciating CSR as a contributory factor to sustainability will enable them to review and redefine their business strategy and practical approach. Accordingly, their focus will be placed on the primal creation of a CSR strategy that places sustainability at the core of their business and, subsequently, leads the formulation of company's SMS in a manner that integrates various economic, social, environmental, along with other applicable regulatory principles and Standards. In such plethora of statutory regulations and management standards, adoption of a structured and integrated CSR business model could eliminate the use of fragmentary and isolated processes promoting, thus, efficiency and, additionally, eliminating resource waste and process duplication at operational level.

\section{Limitations and future research}

There are some limitations associated with this study and their identification and interpretation can transform them to opportunities for future research orientation.

Firstly, it is evident that survey findings are restricted to the perceptions and views of a single target group, namely, the ship management companies. Future research could incorporate perceptions and practices of other maritime stakeholders, such as, charterers, Flag Administrations, Port States etc, enriching, thus, research conclusions. Secondly, the fact that companies declare aware of CSR concept and having, furthermore, adopted CSR into their policy and operations bears a lot of subjectivity and leaves lots of open space for further research on 'how' practically CSR and sustainability have been exercised. Further research is recommended to investigate 'how' practically sustainability has been captured to CSR policy and day to day activities. Hence, interviews with key company personnel, potentially, through a case study research approach, is suggested so as to examine in depth and provide further qualitative information on the way CSR policies and sustainability operating practices are framed within shipping organizations. Thirdly, deductions of this study are limited to the perceptions of maritime companies and do not reflect the level of compliance of the sector against specific CSR and sustainability requirements. Conclusions drawn by this study and applicability of results could be further enhanced and reviewed in cross reference with specific CSR and sustainability 
standards (i.e. GRI Guidelines or UN Global Compact) so as to provide further insights on CSR and sustainability implementation aspects and extent of compliance of the shipping industry.

\section{Conclusions}

In the aftermath of UN 2030 Agenda and SDGs, and having confirmed the lack of empirical research to examine configurations of CSR and sustainability in the tanker and dry cargo maritime sector, this study aimed to investigate latest CSR and sustainability understandings and edifications. To do so, a quantitative research approach was employed. Based on literature review and empirical research, study findings enabled us to reach a deeper understanding on CSR and sustainable development interfaces in the maritime sector. As such, incorporation of CSR principles into ship management practices and increased CSR awareness has been a reality in shipping. However, certification against an official CSR Standard does not constitute a preferred tactic and diffused practice. As this study illustrates, CSR is believed to serve as a significant contributor to the achievement of sustainability. In view of that, CSR is perceived as part of company's business strategy and functions more effectively in favor of sustainability when used as a voluntary strategic management tool and business model (Abrahamsson et al. 2010). Practically, mechanisms should be developed in order to measure, report, review and mitigate negative business impact on sustainability aspects (economic, social and environmental). To do so, as this study revealed, the integrated management system approach, grounded on CSR principles, is indicated as the most effective management pattern to embrace sustainability into company's business practices (Yuen and Lim 2016). One important implication from this study, which regulators would be worth bearing in mind, is that CSR still retains the features of a voluntary, managerial approach. In that sense, and in order to be effective, diffusion and encouragement of CSR application does not essentially necessitates the establishment of a mandatory regulatory CSR regime. Therefore, efforts should be concentrated in the delivery a common language on CSR and develop practical guidelines that will assist shipping companies to integrate sustainability elements into existing safety management system, rather than creating and adopting a new mandatory CSR regulatory regime. Researchers are encouraged to build on this study, by further exploring practical and theoretical associations and implications borne by CSR and sustainability implementation in shipping determining, thus, the principal qualities of a sustainable and responsible maritime company.

\section{Acknowledgments}

The authors wish to thank shipping companies for participating in the survey and offering their valuable expertise and knowledge.

\section{Disclosure statement}

No potential conflict of interest was reported by the authors. 


\section{References}

Asif, M., Searcy, C., Zutshi, A., \& Fisscher, O. A. (2013). An integrated management systems approach to corporate social responsibility. Journal of cleaner production, $56,7-17$.

Abrahamsson, S., Isaksson, R., \& Hansson, J. (2010). Integrated management systems: advantages, problems and possibilities. In 13th ToulonVerona Conference (pp. 1-12).

Alavi, H. A. M. E. D., Hąbek, P. A. T. R. Y. C. J. A., \& Čierna, H. (2016). Corporate social responsibility and self-regulation. MM Science Journal, $2016,1121$.

Acciaro, M. (2014). A real option application to investment in low-sulphur maritime transport. International Journal of Shipping and Transport Logistics, 6(2), 189-212.

Baker, C. C., McSweeney, K. P., \& McCafferty, D. B. (2002). Human factors and ergonomics in safe shipping: the ABS approach. Proceedings of the Maritime Operations. Washington, DC.

Bantekas, I. (2004). Corporate social responsibility in international law. BU Int'I LJ, 22, 309.

Behringer, K., \& Szegedi, K. (2016). The role of CSR in achieving sustainable development-Theoretical approach. European Scientific Journal, ESJ, 12(22).

Burns, R. B., \& Bursn, R. B. (2000). Introduction to research methods.

Bezerra, R. F., Jalloh, S., \& Stevenson, J. (1998). Formulating hypotheses graphically in social research. Quality and Quantity, 32(4), 327-353.

Bowen, E.H. and Haire, M. (1975). A Strategic posture towards corporate social responsibility', California Management Review, $18,49-58$.

Carroll, A.B. (2000). Ethical Challenges for Business in the New Millennium: Corporate Social Responsibility and Models of Management Morality. Business Ethics Quarterly, 10 (1), pp. 33-42.

Campbell, J. L. (2007). Why would corporations behave in socially responsible ways? An institutional theory of corporate social responsibility. Academy of management Review, 32(3), 946-967.

Chandler Jr, A. D. (1962). 1998, Strategy and Structure: Chapters in the History of the American Industrial Enterprise.

Chakraborty, U. K. (2015). Developments in the Concept of Corporate Social Responsibility (CSR). The Researchers' International Research Journal, 1(1), 23-45.

Casadesus-Masanell, R., \& Ricart, J. E. (2010). From strategy to business models and onto tactics. Long range planning, 43(2-3), 195-215.

Coady, L., Lister, J., Strandberg, C., \& Ota, Y. (2013, November). The role of corporate social responsibility (CSR) in the international shipping sector. In Northern European Symposium on CSR in Shipping, Copenhagen (Vol. 12).

Davis, K. (1960). Can business afford to ignore social responsibilities? California Management Review, 2(3), pp. 70-76.

Dey, M., Sircar, S. (2012). „Integrating corporate social responsibility initiatives with business strategies: a study of some Indian companies”, The IUP Journal of Corporate Governance, vol. XI (1), pp. 36-51.

Dewangga, A., Goldsmith, S., \& Pegram, N. (2008). Social responsibility guidelines \& sustainable development: Integrating a common goal of a sustainable society (Unpublished Masters dissertation). Blekinge Institute of Technology, Karlaskrona, Sweden.

Deming, W. E. (2018). The new economics for industry, government, education. MIT press.

Dooley, D., \& Gullickson, T. (1995). Social research methods. Psyccritiques, 40(10), 1016. 
Ehlers, P. (2016). Blue growth and ocean governance-how to balance the use and the protection of the seas. WMU Journal of Maritime Affairs, 15(2), 187-203.

Elkington, J. (1994). Towards the sustainable corporation: Win-win-win business strategies for sustainable development. California management review, 36(2), 90-100.

Ebner, D., \& Baumgartner, R. J. (2006, September). The relationship between sustainable development and corporate social responsibility. In Corporate responsibility research conference (Vol. 4, No. 5.9, p. 2006). Queens University, Belfast Dublin.

EMSA 2019, European maritime Safety Agency (EMSA), Available from: http://www.emsa.europa.eu/implementationtasks/environment/sustainable-toolbox.html, Accessed: 20/01/2019

Field, A., Miles, J., \& Field, Z. (2012). Discovering statistics using R. Sage publications.

Friedheim, R. L. (1999). Ocean governance at the millennium: where we have been-where we should go. Ocean \& coastal management, 42(9), 747-765.

Friedman, M. (2007). The social responsibility of business is to increase its profits. In Corporate ethics and corporate governance (pp. 173178). Springer, Berlin, Heidelberg.

Fafaliou, I., Lekakou, M., \& Theotokas, I. (2006). Is the European shipping industry aware of corporate social responsibility? The case of the Greek-owned short sea shipping companies. Marine Policy, 30(4), 412-419.

Ganescu, M. C. (2012). Corporate social responsibility, a strategy to create and consolidate sustainable businesses. Theoretical \& Applied Economics, 19(11).

Gibson, R.; Hassan, S.; Holtz, S.; Tansey, J. \& Whitelaw, G. 2005. Sustainability Assessment-Criteria and Processes. Earthscan. London, UK. Giovannoni, E., \& Fabietti, G. (2013). What is sustainability? A review of the concept and its applications. In integrated reporting (pp. 21-40). Springer, Cham.

Giesen, E., Riddleberger, E., Christner, R., \& Bell, R. (2010). When and how to innovate your business model. Strategy \& Leadership, 38(4), 17-26. Harreld, J. B., O'Reilly III, C. A., \& Tushman, M. L. (2007). Dynamic capabilities at IBM: Driving strategy into action. California management review, 49(4), 21-43.

Huge, J., \& Waas, T. (2011). Corporate social responsibility for sustainable development-reflections on theory, practice and on the role of government. Steunpunt Beleidsrelevant Onderzoek, 12-13.

Imperatives, S. (1987). Report of the World Commission on Environment and Development: Our Common Future. Accessed Feb, 10.

International Labour Organization, \& International Labour Office. Director-General. (2007). Equality at Work: Tackling the Challenges: Global Report Under the Follow-up to the ILO Declaration on Fundamental Principles and Rights at Work (Vol. 1). International Labour Organization.

Jørgensen, T. H., Remmen, A., \& Mellado, M. D. (2006). Integrated management systems-three different levels of integration. Journal of cleaner production, $14(8), 713-722$.

Khan, M. T., Khan, N. A., Ahmed, S., \& Ali, M. (2012). Corporate social responsibility (CSR)-definition, concepts and scope. Universal Journal of Management and Social Sciences, 2(7), 41-52.

Kurucz, E. C., Colbert, B. A., \& Wheeler, D. (2008). The business case for corporate social responsibility. In The Oxford handbook of corporate social responsibility.

Kristiansen, S. (2013). Maritime transportation: safety management and risk analysis. Routledge.

Kunnaala, V., Rasi, M., \& Storgård, J. (2013). Corporate social responsibility and shipping views of Baltic Sea shipping companies on the benefits of responsibility. 
Kunnaala, V., \& Viertola, J. (2014). IMISS 2013-Proceedings of the International Scientific Meeting for Corporate Social Responsibility (CSR) in Shipping 2nd International Maritime Incident and Near Miss Reporting Conference 11-12 June 2013, Kotka, Finland.

Lekakou, M., Theotokas, I., \& Stefanidaki, E. (2016). Corporate social responsibility in the shipping industry. In Research handbook on corporate social responsibility in Context. Edward Elgar Publishing.

Lee, B. X., Kjaerulf, F., Turner, S., Cohen, L., Donnelly, P. D., Muggah, R. \& Waller, I. (2016). Transforming our world: implementing the 2030 agenda through sustainable development goal indicators. Journal of public health policy, 37(1), 13-31.

Lund-Thomsen, P., Poulsen, R. T., \& Ackrill, R. (2016). Corporate social responsibility in the international shipping industry: state-of-the-art, current challenges and future directions. The Journal of Sustainable Mobility, 3(2), 3-13.

Maignan, I., Ferrell, O. C., \& Ferrell, L. (2005). A stakeholder model for implementing social responsibility in marketing. European journal of marketing, 39(9/10), 956-977.

Maon, F., Lindgreen, A., \& Swaen, V. (2010). Organizational stages and cultural phases: A critical review and a consolidative model of corporate social responsibility development. International Journal of Management Reviews, 12(1), 20-38.

Madrakhimova, F. (2013). History of development of corporate social responsibility. Journal of Business and Economics, 4(6), 509-520.

Markides, C. C. (2013). Game-changing strategies: How to create new market space in established industries by breaking the rules. John Wiley \& Sons.

Maria Gjølberg, Tore Longva, Kjersti Aalbu, (2017). Sustainable Development Goals: Exploring maritime Opportunities, DNV-GL, Report Commissioned by: NORWEGIAN SHIPOWNERS' ASSOCIATION.

McAdam, R., \& Leonard, D. (2003). Corporate social responsibility in a total quality management context: opportunities for sustainable growth. Corporate Governance: The international journal of business in society, 3(4), 36-45.

McDonald, M., Mors, T.A., Phillips, A., 2003. Management system integration: can it be done? Quality Progress 36 (10), $67 \mathrm{e} 74$.

McWilliams, A; Siegel, D. (2001). Corporate Social Responsibility: A theory of the firm's perspective. Academy of Management Review. 26: 117127.

Myers, L., \& Sirois, M. J. (2004). Spearman correlation coefficients, differences between. Encyclopedia of statistical sciences, 12.

Murphy, P. E. (1978). An evolution: Corporate social responsiveness. University of Michigan Business Review, 6 (30), pp. 19-25.

Michael, Porter E. "What is strategy." Harvard Business Review 74.6 (1996): 61-78.

Mustafa, R., \& Werthner, H. (2011). Business models and business strategy-phenomenon of explicitness. Framework, 6(1), 14-29.

Morell, J. B. (1992). The law of the sea: an historical analysis of the 1982 treaty and its rejection by the United States (p. 2). McFarland.

Nilsson, M., Griggs, D., \& Visbeck, M. (2016). Policy: map the interactions between Sustainable Development Goals. Nature News, 534(7607), 320 .

Neuman, W. L. (2013). Social research methods: Qualitative and quantitative approaches. Pearson education.

Nam, U. V. (2015). Transforming our world: The 2030 agenda for sustainable development. Division for Sustainable Development Goals: New York, NY, USA.

Norwegian Shipowners' Association (NSA), Corporate Social Responsibility Report, UN Global Compact, Available from: https://rederi.no/globalassets/dokumenter/alle/fagomrader/csr/generelt/csr-rapport.pdf, Accessed: 15/01/2019

Oskarsson, K., \& Von Malmborg, F. (2005). Integrated management systems as a corporate response to sustainable development. Corporate Social Responsibility and Environmental Management, 12(3), 121-128. 
Osterwalder, A. (2004). The business model ontology a proposition in a design science approach (Doctoral dissertation, Université de Lausanne, Faculté des hautes études commerciales).

Pardy, W., \& Andrews, T. (2009). Integrated management systems: Leading strategies and solutions. Government Institutes.

Pawlik, T., Gaffron, P., \& Drewes, P. A. (2012). Corporate social responsibility in maritime logistics. In Maritime Logistics: Contemporary Issues (pp. 205-226). Emerald Group Publishing Limited.

Prizing-Jorgensen, P. M., \& Farrag, A. (2010). Sustainability trends in the container shipping industry: A future trends research summary. Business for Social Responsibility.

Pike, K., Butt, N., Johnson, D., \& Walmsley, S. (2013). Global sustainable shipping initiatives. Audit and overview 2011. A Report for WWF. Southampton Solent University, School of Maritime and Technology, East Park Terrace, Southampton SO14 0YN.

Petrovic, O., Kittl, C. and Teksten, R.D. (2001) Developing Business Models for e-Business, International Conference on Electronic Commerce 2001, Vienna, October 31 - November 4.

Poulovassilis, A., \& Meidanis, S. (2013). Sustainability of shipping-Addressing corporate social responsibility through management systems. Saatavilla: http://www. commonlawgic.org/sustainabilityof-shipping. html [2.8. 2013].

Progoulaki, M., \& Roe, M. (2011). Dealing with multicultural human resources in a socially responsible manner: a focus on the maritime industry. WMU journal of maritime affairs, 10(1), 7-23.

Raišienè, A. G. (2011). Advantages and limitations of integrated management system: the theoretical viewpoint. Social Technologies, 1(1), 2536.

Rebekić, A., Lončarić, Z., Petrović, S., \& Marić, S. (2015). PEARSON'S OR SPEARMAN'S CORRELATION COEFFICIENT-WHICH ONE TO USE? Poljoprivreda (Osijek), 21(2), 47-54.

Reinhardt, F. L., \& Stavins, R. N. (2010). Corporate social responsibility, business strategy, and the environment. Oxford Review of Economic Policy, 26(2), 164-181.

Reid, D. Sustainable Development - An Introductory Guide; Earthscan: London, UK, 2005.

Rochlin, S., Witter, K., Monaghan, P., \& Murray, V. (2005). Putting the corporate into corporate responsibility. In Accountability forum: Corporate responsibility and core business (pp. 5-13).

Sachs, J. D. (2012). From millennium development goals to sustainable development goals. The Lancet, 379(9832), $2206-2211$.

Shi, Y. (2016). Reducing greenhouse gas emissions from international shipping: Is it time to consider market-based measures?. Marine Policy, $64,123-134$

Sekimizu, K. (2012). A concept of a sustainable Maritime Transportation System.

Ships, S. (1994). Cleaner Seas (Report of Lord Donaldson's Inquiry into the Prevention of Pollution from Merchant Shipping).

Szegedi, K. (2010). The concept and development tendencies of corporate social responsibility. Theory, Methodology, Practice, 5(1), 67. Sisteré Ibars, I. (2013). Corporate Social Responsibility in the Shipping Business.

Stafford-Smith, M., Griggs, D., Gaffney, O., Ullah, F., Reyers, B., Kanie, N., \& O'Connell, D. (2017). Integration: the key to implementing the Sustainable Development Goals. Sustainability Science, 12(6), 911-919.

Tan, P. N., Kumar, V., \& Srivastava, J. (2004). Selecting the right objective measure for association analysis. Information Systems, 29(4), 293313.

Teece, D.J. (2010). “Business Models, Business Strategy and Innovation”, Long Range Planning, 43, pp. 172-194. 
Toffel, M. W., Hill, N., \& McElhaney, K. A. (2003). Developing a management systems approach to sustainability at BMW Group. Corp. Environ. Strategy, 10, 29-39.

Theilkemeier, L., Taheri, A., \& Dreveborn, I. (2010). Corporate Social Responsibility: the legal framework of CSR.

United Nations, REFLECTIONS ON SOCIAL ACCOUNTABILITY, Catalyzing democratic governance to accelerate progress towards the Millennium Development Goals, July 2013, Available from;

http://www.undp.org/content/dam/undp/documents/partners/civil_society/publications/2013_UNDP_Reflections-on-SocialAccountability_EN.pdf, Accessed: 19/03/2017

United Nations, Environment (2017): Realizing Integrated Regional Oceans Governance - Summary of case studies on regional cross-sectoral institutional cooperation and policy coherence, Available from:

https://wedocs.unep.org/bitstream/handle/20.500.11822/21692/realizing_integrated_reg_oceans_governance.pdf?sequence=1\&isAllowed=y, Accessed: 15/06/2018

United Nations, Review of Maritime Transport, 2017, UNCTAD/RMT/2017 UNITED NATIONS PUBLICATION, Available from: http://unctad.org/en/PublicationsLibrary/rmt2017_en.pdf, Accessed: 20/05/2018

United Nations, “Sustainable Development: IMO's contribution beyond Rio+20" Wednesday, 25 September 2013, Available from: https://www.unric.org/en/latest-un-buzz/28709-sustainable-development-imos-contribution-beyond-rio20?format=pdf, Accessed: 22/06/2018

United Nations, THE OCEAN AND THE SUSTAINABLE DEVELOPMENT GOALS UNDER THE 2030 AGENDA FOR SUSTAINABLE DEVELOPMENT A TECHNICAL ABSTRACT OF THE FIRST GLOBAL INTEGRATED MARINE ASSESSMENT, eISBN 978-92-1-361371-9, 2017, Available from: http://www.un.org/depts/los/global_reporting/8th_adhoc_2017/Technical_Abstract_on_the_Ocean_and_the_Sustainable_Development_Goals_ under_the_2030_Agenda_for_Susutainable_Development.pdf, Accessed: 05/01/2019

UNIDO 2013, United Nations Industrial Development Organization, CSR will help enterprises achieve Sustainable Development Goals (SDGs), Brussels, 2015, Available from: https://europa.eu/capacity4dev/unido/blog/csr-will-help-enterprises-achievesustainable-development-goalssdgs, Accessed: 10/05/2017

Van Marrewijk, M. (2003). Concepts and definitions of CSR and corporate sustainability: Between agency and communion. Journal of business ethics, 44(2-3), 95-105.

Van Leeuwen, J. (2015). The regionalization of maritime governance: Towards a polycentric governance system for sustainable shipping in the European Union. Ocean \& Coastal Management, 117, 23-31.

Venkatramann, N. and Henderson, J.C. (1998) Real Strategies for Virtual Organizing, Sloan Management Review, 40 (1), $33-48$.

Weber, M. (2008). The business case for corporate social responsibility: A company-level measurement approach for CSR. European Management Journal, 26(4), 247-261.

Wilson, M. (2003). Corporate sustainability: What is it and where does it come from. Ivey business journal, 67(6), 1-5.

Wright, T. (2000). IMS-three into one will go!: the advantages of a single integrated quality, health and safety, and environmental management system. The Quality Assurance Journal: The Quality Assurance Journal for Pharmaceutical, Health and Environmental Professionals, 4(3), 137142.

Yuen, K. F., \& Lim, J. M. (2016). Barriers to the implementation of strategic corporate social responsibility in shipping. The Asian Journal of Shipping and Logistics, 32(1), 49-57. 